\title{
ヌエンアンチュアン 論文内容の要旨
}

主 論 文

Simulation of orthodontic tooth movement during the activation of an innovative design of closing loop using the finite element method

有限要素法を用いた、革新的な設計デザインによる空隙閉鎖ループ活性化時の 矯正力による歯の移動シミュレーション

Tuan Anh Nguyen, Ryo Hamanaka, Sachio Jinnai, Hiroya Komaki, Satoshi Yamaoka, Jun-ya Tominaga, Yoshiyuki Koga, Noriaki Yoshida ヌエン アンチュアン、濱中僚、陣内祥男、小牧博也、山岡 智、富永淳也、 古賀義之、吉田教明

(American Journal of Orthodontics and Dentofacial Orthopedics 掲載予定 印刷中)

長崎大学大学院医歯薬学総合研究科医療科学専攻 (主任指導教員：吉田教明教授）

緒 言

エッジワイズ装置を用いた、抜歯を伴う矯正治療のためのツイードテクニックが確 立されて以来、空隙閉鎖法にはループメカニクスが広く使用されてきた。もう一つの 空隙閉鎖法のスライディングメカニクスがアーチワイヤーとブラケット間に摩擦が 生じるために歯の移動速度が減少する副作用があるのとは対照的に、ループメカニク スは摩擦を生じない治療システムであり、このために歯の移動を適正に制御するため のあらかじめ計画されたフォースシステム（力系）を移動しようとする歯に与えるこ とが可能である。しかしながら、ループメカニクスもいくつかの短所を有し、特にゲ ーブルベンドをループに組み込む場合には、過大な矯正力を歯に及ぼす。また、大き なワイヤーサイズを用いるとさらに矯正力を大きくしてしまうため、剛性の高いワイ ヤーを使用する 0.022 スロットシステムでは、ループメカニクスを使用しにくいとい う欠点があった。さらなる問題点として、前歯の適正なトルクコントロールを達成す るための十分大きなモーメント・フォース比（ M/F 比）を発揮できず、小さい值に とどまることが知られている。これまでに、Sumi らがループの先端から $3 \mathrm{~mm}$ のワ イヤー断面厚みを $50 \%$ 削合した teadrop ループのデザインを考案し、このループの 力学的特性として、鿏引力が減少し、 $\mathrm{M} / \mathrm{F}$ 比が飛躍的に増加し、有効な前歯のトルク コントロールが達成できることを報告した。

本研究では、長期的な歯の移動解析を行い、この革新的なデザイン設計のループを 用いて空隙閉鎖した場合の前歯ならびに大臼歯移動制御の効果を明らかにすること を目的とする。 
対象と方法

まず、C Tにて撮影された画像を基に、3 次元画像処理・編集ソフトウェア Mimics を用いて上顎中切歯から第 2 大臼歯までの歯を三次元構築した。次に、有限要素解析 プリ・ポストプロセッサソフトウェア Patran にて、歯根膜や歯槽骨、アーチワイヤ 一などのモデルの作成や有限要素メッシュの作成を行った。 $0.022 \times 0.028$ インチのブ ラケットと、0.019×0.025 インチのステンレススティールの teadrop ループを組み 込んだアーチワイヤーをモデルに追加した。アーチワイヤーのモデルは 5 種類作成し、 ループ先端を削合しないモデル、ループの先端から $3 \mathrm{~mm}$ のワイヤー断面厚みを $50 \%$ 削合したモデル、さらにゲーブルベンドを $5^{\circ} 、 10^{\circ} 、 15^{\circ}$ 組み込んだモデルとした。ル ープを $1 \mathrm{~mm}$ 活性化した際の中切歯および第一大臼歯の移動動態を解析し、比較した。

結果

ループの先端から $3 \mathrm{~mm}$ のワイヤー断面厚みを $50 \%$ 削合した teadrop ループでは、 削合しないループと比較して、上顎中切歯の舌側歯冠傾斜度が $1.56^{\circ}$ から $0.78^{\circ}$ 八半分 に減少した。ループにゲーブルベンドを $5^{\circ}$ 組み込むと、さらに $0.50^{\circ}$ に減少し、1 $10^{\circ}$ 組 み込むと、逆に $0.04^{\circ}$ の舌側歯根傾斜を示し、傾斜方向が逆転した。1 $5^{\circ}$ 組み込むと、 舌側歯根傾斜が $1.14^{\circ}$ に増加した。大臼歯の移動動態に関して、ループ先端の削合に より、大臼歯の近心傾斜度が 0.84 から $0.35^{\circ}$ へ減少した。ループにゲーブルベンドを $5^{\circ}$ 組み込むと、逆に $0.02^{\circ}$ の遠心傾斜となり、傾斜方向が逆転した。1 0 組み込むと、 $0.20^{\circ} 、 15^{\circ}$ 組み込むと、 $0.52^{\circ}$ に遠心傾斜度が増加した。

考察

Teadrop ループ先端から $3 \mathrm{~mm}$ のワイヤー断面厚みを $50 \%$ 削合すると、空隙閉鎖 時において、中切歯の舌側歯冠傾斜と大臼歯の近心傾斜を抑制し、抜歯窩への倒れ込 みを減じる効果が示された。さらにループを組み込むことにより、前歯のトルクコン トロールの効果を高め、さらには大臼歯の固定効果を増強することが明らかとなった。 単純かつ革新的なデザインのループを用いることにより、空隙閉鎖時の副作用とし てのボーイング・エフェクトと呼ばれる、抜歯窩への倒れ込みを防止し、前歯のより 適正なトルクコントロールの達成に有効なことが示唆された。

結 論

単純形状の teardrop ループの先端 $3 \mathrm{~mm}$ のワイヤー断面厚みを $50 \%$ 削合すること、 さらにはゲーブルベンドを組み込むことにより、前歯の効果的なトルクコントロール だけでなく、大臼歯の固定効果を増強することが可能なことが示唆された。 